\title{
INFLUENCE OF ENVIRONMENT ON SEXUAL EXPRESSION IN HEMP
}

JoHN H. SCHAFFner

(WITH PLATE XI AND ONE FIGURE)

The study of hemp, Cannabis sativa L., was originally undertaken by the writer to determine what influence the environment might have on the sex ratio between staminate and carpellate plants. During the progress of the investigation, other problems in relation to sex presented themselves which were of more immediate importance than the mere determination of the factors which might be the cause of variation in the expected number of staminate or carpellate individuals. The first plantings were made in the fall of I9I3, but little was accomplished at that time because the department of botany was preparing to move into a new building, and, as is commonly the case in such ventures, several years were consumed in bringing the new plant into proper working order. The investigation was resumed in the fall of 1916 , from which time on plantings have been made each year out of doors in the spring and each winter in thegreenhouse, excepting thewinter of $1917^{-1} \mathrm{Ig} I 8$, which was spent in Florida.

As stated, it soon became evident that far more fundamental problems were presented for solution than the mere changing of sex ratios. Intermediate plants appeared, bearing both stamens and carpels. There was also an endless profusion of abnormal flowers involving all sorts of sexual expressions; and, most remarkable of all, complete reversal of sexual expression under the influence of an abnormal environment presented itself as the most interesting phenomenon to be studied. The last three years, therefore, have mainly been devoted to a study of abnormal flowers and sex reversal.

Examination of the plants in the beds was greatly facilitated by the use of a Bausch and Lomb binocular magnifier. The

${ }^{x}$ Papers from the Department of Botany, the Ohio State University, no. 120. 
detailed study of flowers and other parts was carried on mainly with the aid of a binocular dissecting microscope.

Previous reference to the abnormal behavior of the hemp under the imposed abnormal conditions was made by the writer (3) as follows: "Not only did typical staminate plants sometimes produce bisporangiate flowers with more or less normal gynoecia, but some carpellate plants even produced stamens. This in spite of the fact that the plants were differentiated in their vegetative parts as typically carpellate." A preliminary notice (5) of the complete reversal of sex was published in I9I9. In I9I6 PRICHARD (2) published the results of experiments on hemp, in which changes in sexual expression were shown to take place as the result of various treatments, such as removal of flowers, etc.

\section{Record of seed and plantings}

The original seeds were bought from a seed house in Columbus, Ohio, their origin being unknown.

Plot I, planted January 1917 , in botanical greenhouse. Numerous sex intergrades and sex reversals were observed. Intermediate plants and abnormal flowers studied.

Plot 2, planted in the garden May I9I8, with part of the original seeds. The plants were apparently all pure carpellate and pure staminate. No intermediates of any kind were found.

Plot 3, planted in the greenhouse on December 23, 1918. Seeds from individual plant of plot no. 2. Flowers began to open February I, I9I9. There were 73 carpellate and 77 staminate plants. Many were intermediate in sexual expression, or later reversed their sexual condition. These plants were mainly studied for abnormalities in sexual expression in the flowers.

Plot 4, planted in the greenhouse January 22, I9I9. Plants in bloom on March I7. Seeds from an individual of plot 2.

Plot 5, planted in the greenhouse February I, I9I9. Seeds from an individual of plot 2. Seeds came up February 6 and 7 . Plants began to bloom March 5 .

Plot 6, planted in the garden early in May igrg. Seeds from an individual of plot 2. In this plot there were I24 pure carpellate and 122 pure staminate plants. There were no intermediates and no sex reversals of any kind. 
Plot 7 , planted in the garden June 24 , I919. Seeds from a plant of plot 2. In bloom August 18. There were 86 pure carpellate and 83 pure staminate plants. No intermediates or reversals of any kind appeared.

Plot 8, planted in the greenhouse November 26, I919. Seeds from a red colored individual of plot 7 . First flowers opened January 6, 1920. Plants dying and the last pulled up May I2, I920.

Plot 9, planted in the greenhouse November 26, I919, with seeds from a normal green leaved individual from plot 7 . First flowers opened January 6, I920. All the plants had been pulled up or were dying May I2, I920.

Plot Io, planted in the greenhouse on the north side December 4, I919, with seeds from an individual of plot 7 . First flowers in bloom January I3, I920. All the plants had reversed their sex or were dying by May 4, I920.

Plot II, planted in the greenhouse on the north side December I9, r9r9. Seeds from an individual of plot 7. The plants had two pairs of leaves when the flowers began to open January 30 , 1920. All of the plants had reversed their sex or were dying May I, I920.

Plot I2, planted in the greenhouse on the north side on December 19, 1919. Seeds from the red leaved individual used for plot 8 . Flowers began to open on February I, I920, when most of the individuals had but two pairs of leaves. All of the plants had reversed their sex or were dying May 4, I920.

Plot 13 , planted in the greenhouse on December I9, I9I9. Seeds from the same red leaved individual as used for plots 8 and $\mathrm{I} 2$. Flowers began to open February 6, I920. All plants had shown sex reversal or were dying and pulled up by May 12,1920 .

Plot 14, planted December I9, I919, in the greenhouse with seeds from an individual of plot 7 . Flowers were opening on February 6, 1920. All plants had reversed their sex or were dying and pulled up by May ז2, r9zo.

Plot I $_{5}$, consisting of special plantings from seeds obtained from individuals raised in the greenhouse in the winter of I9I8-1919: (I) Seeds from a plant which produced staminate flowers before it died; two plants were obtained, one staminate and one 
carpellate; both were intermediate in sexual expression and of the same character as intermediate plants obtained from seeds from pure parents; (2) seeds from a carpellate plant which developed three staminate flowers before it died; three plants were obtained, which were carpellate but produced stamens before they died; two individuals became decidedly staminate and one slightly so; (3) seeds from an apparently pure carpellate plant but pollinated with pollen from an intermediate staminate plant; two carpellate plants were secured which later produced stamens.

\section{Cultural conditions}

The various plantings in the garden were perfectly normal, and not a single individual gave any indication of an intermediate or monoecious condition, and there was no sex reversal. The plants raised in the greenhouse during the winter were growing in a very abnormal environment. The aim was to change the environmental factors controlling growth and nutrition as much as possible without interfering entirely with reproduction. Accordingly a rich soil was used, with abundance of water and the ordinary temperatures used in greenhouses during the winter months. The light conditions were very low, the soil in the benches was shallow, about 3 in. deep, and the main source of heat was immediately beneath the benches. Under these conditions the hemp matured very early, and in those plants which had the poorest illumination the inflorescence usually appeared when but two pairs of leaves were present. The plants were never more than a few inches high, and the first staminate flowers usually opened in 32 or 33 days from the time of planting.

No attempt was made to discover which abnormal condition or set of conditions was mainly responsible for the changed morphology and sexuality, but apparently the reduction in the quantity and intensity of light, with its effect on the nutritive process, is the chief factor involved. Good illumination with low temperature would probably give much the same results. The influence of the abnormal conditions on sexual expression, as will appear later, is very great. Commonly more than 75 per cent of the individuals showed mixed sexual expression or a reversal of the sex before the 
end of life. The staminate plants usually began to die soon after the first inflorescence had come to bloom, while the carpellate plants usually lived for several months, after the first seeds had ripened, and continued to bloom from new lateral branches. Occasionally a carpellate plant was entirely rejuvenated and put out a second system of shoots which had all the signs and characteristics of the original sprout coming from the seed. A few staminate plants transplanted and carefully nurtured also showed some rejuvenation and continued to produce branches below for some time, but they mostly became senile and died after the blooming of the first inflorescence was completed.

\section{Sexual dimorphism}

Hemp as grown under normal conditions is distinctly dimorphic, both as to flowers and vegetative characters. The vegetative dimorphism, however, is much greater in plants grown under the abnormal greenhouse environment (text fig. I, $a$ and $b$ ). The plants experimented with, of course, had their sexual state already established in the embryo of the seed, and whatever changes were induced had their origin during the vegetative growth, between the period of sprouting and the origin of the

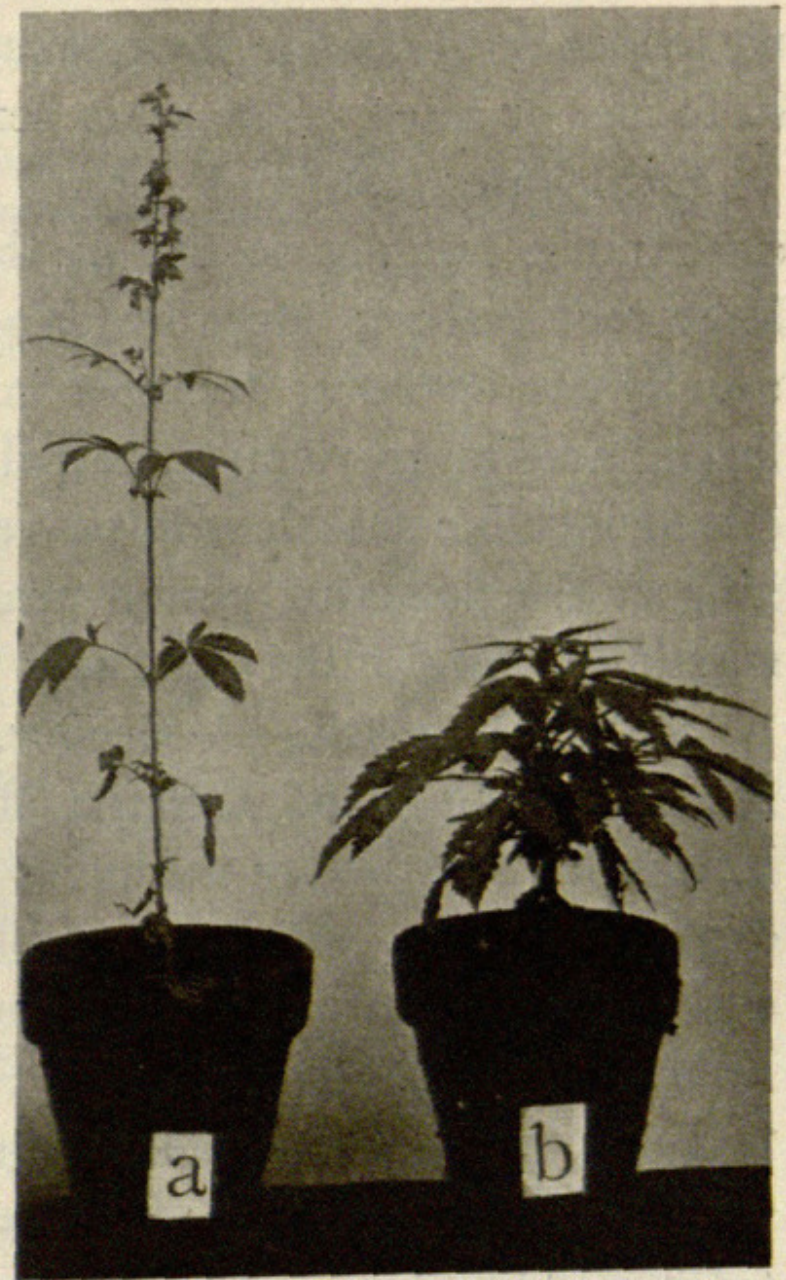

FIG. I.-Cannabis sativa: staminate (a) and carpellate plant $(b)$ of same age, grown in greenhouse in winter, showing decided sexual dimorphism; each plant showed reversal of sex and produced sporophylls of opposite nature; plants transferred from plot in greenhouse to pots just before being photographed. incepts of the opposite types of flowers. This must be true for all plants, except perhaps for the few intermediate individuals in which the confused condition of sexual expression might have been due to a definite genetic constitution which would allow of a mixed sexual 
expression under any ordinary environmental conditions. The only other available hypothesis, according to the writer's views, would be to assume that sex is not determined in the seed, but only after vegetative growth has begun.

The ratio between carpellate and staminate plants is $\mathrm{I}: \mathrm{I}$, with considerable fluctuation in either direction for any given planting. The vegetative dimorphism is the same for individuals which show no tendency to change their sexual expression and those which do so sooner or later. The main sexual differences are as follows.

Carpellate plant.-A broad flat crown of leaves; vigorous appearance but not so tall as the staminate plant; robust stem; large root system; large leaf blades with more numerous leaflets, usually five or more; terminal inflorescence usually leafy; petioles longer and more robust; carpellate flowers with the perianth a closed sacklike sheath with no vestigial stamens; weight at beginning of the flowering period nearly twice as much as that of the staminate plant of the same age; a longer period of life and growth.

Staminate plant.-A slender, spindling habit and taller than the carpellate plant through the very rapid elongation of the internodes just before anthesis; root system smaller than in the carpellate plant; smaller leaf blades with fewer leaflets; shorter and more slender petioles; terminal inflorescence with few or no leaves; staminate flowers with $3-6$ separate sepals (usually 4 or 5) with no vestige of a gynoecium; weight about half that of the carpellate plant at time of anthesis; a much shorter life than the carpellate plant.

The weights of a dozen individuals of the same age, from the same plot, were determined as follows. Staminate and carpellate plants were cut off at the cotyledon node and immediately placed in glass jars with ground glass stoppers. They were thus weighed without loss of water. After weighing, the stoppers were removed and the jars with the specimens kept in the oven at $50^{\circ} \mathrm{C}$. After three days they were placed in an oven at $110^{\circ} \mathrm{C}$. and heated for two hours. The stoppers were then replaced, and after cooling the final weights were made of the dried plants. Table I gives the individual weights, the totals, and the averages. It will be seen that the carpellate plants average nearly twice the weight 
of the staminate plants. Probably if the root systems had also been weighed the ratio would have been very nearly 2: I. Apparently there is very little if any difference in the ratio between the dry matter and water of the carpellate plants and that of the staminate plants. On account of the dêcided vegetative dimorphism of the winter plants, a number of interesting differential physiological studies might easily be carried on with the hemp.

TABLE I

WEIGHTS OF I 2 PLANTS AT BEGINNING OF ANTHESIS

\begin{tabular}{|c|c|c|c|c|c|c|c|}
\hline \multirow{2}{*}{$\begin{array}{l}\text { Plant } \\
\text { No. }\end{array}$} & \multicolumn{3}{|c|}{ CARPELLATE } & \multirow{2}{*}{$\begin{array}{c}\text { Plant } \\
\text { No. }\end{array}$} & \multicolumn{3}{|c|}{ Staminate } \\
\hline & Green weight & Dry weight & Water & & Green weight & Dry weight & Water \\
\hline $\begin{array}{r}1 \ldots \\
3 \ldots \\
5 \ldots \\
7 \ldots \\
9 \ldots \\
11 \ldots\end{array}$ & $\begin{array}{l}3.35 \mathrm{gm} . \\
3.01 \\
2.70 \\
2.42 \\
2.95 \\
2.58\end{array}$ & $\begin{array}{l}0.5^{8} \mathrm{gm} . \\
0.62 \\
0.5^{2} \\
0.44 \\
0.53 \\
0.45\end{array}$ & $\begin{array}{l}2.77 \mathrm{gm} . \\
2.39 \\
2.18 \\
1.98 \\
2.42 \\
2.13\end{array}$ & $\begin{array}{r}2 \ldots \\
4 \ldots \\
6 \ldots \\
8 \ldots \\
10 \ldots \\
12 \ldots\end{array}$ & $\begin{array}{l}\text { I. } 91 \mathrm{gm} \text {. } \\
2.25 \\
\mathrm{I} .47 \\
2.17 \\
0.87 \\
1.03\end{array}$ & $\begin{array}{l}0.38 \mathrm{gm} \text {. } \\
0.34 \\
0.31 \\
0.41 \\
0.17 \\
0.20\end{array}$ & $\begin{array}{l}\text { I. } 53 \mathrm{gm} . \\
1.91 \\
\text { I.16 } \\
\text { 1. } .6 \\
0.70 \\
0.82 \\
\end{array}$ \\
\hline Total & 17.01 & 3.14 & 13.87 & Total & $9 \cdot 70$ & I. $8 \mathrm{r}$ & 7.89 \\
\hline $\begin{array}{c}\text { Aver- } \\
\text { age. }\end{array}$ & 2.835 & .523 & 2.311 & $\begin{array}{c}\text { Aver- } \\
\text { age }\end{array}$ & I. 616 & .301 & I. $3 I_{5}$ \\
\hline
\end{tabular}

Abnormal, irregular, and bisporangiate flowers

Plots I and 3 were mainly studied for irregularities in the flowers. These were so remarkable that chief attention was diverted to their morphology in relation to sexual expression, while the remaining greenhouse plantings were studied for sex ratios and sex reversals. In all the winter plantings there was a great assortment of sexual expression in the flowers. One could find almost any conceivable combination of perfect and imperfect sporophylls. Figs. $\mathrm{I}-\mathrm{I} 2$ were selected, not as an exhaustive set of examples, but simply to indicate the general character of the confusion displayed by the spore bearing organs. They show that any attempt to bring these sexual expressions within the bounds of Mendelian heredity would be out of the question. Fig. I is a typical staminate flower from a staminate plant, and fig. 2 is a normal carpellate flower, with the sheath cut open, 
from a carpellate plant. The staminate flower has four distinct sepals and the normal gynoecium has two stigmas. In some cases nearly typical carpellate flowers appear on staminate plants (fig. 3), and carpellate plants often bear normal staminate flowers toward the end of their life. A common abnormality is the development of a typical stigma or one of varying degrees of perfection at the outer end of an anther (figs. 4, 7, 9a, also 6, 8, II). Occasionally a stamen grows directly out of the side of an ovulary (fig. 5), or the ovulary may have more or less perfectly developed microsporangia on one side. Fig. Io represents such a structure from the tip of the inflorescence of a carpellate plant. This flower has the characteristic staminate perianth, although in other respects it is more carpellate in nature. Figs. 6 and 7 represent two types of abnormal flowers, both from a carpellate plant. Fig. 6 has one good and nearly normal stamen. Fig. 8 is a stamen-carpel complex from the center of a staminate flower with four normal stamens; taken from a staminate plant. Apparently an attempt was made to develop a normal bicarpellary gynoecium. The one side has an imperfect ovulary with a normal stigma, while the other has a distorted anther with two microsporangia ending in an imperfect stigma. Figs. 9 and $9 a$ represent a flower from a staminate plant with an imperfectly developed gynoecium in the center. The separated stamen (fig. $9^{a}$ ) has a well developed stigma, and one other stamen has a rudimentary structure at the tip which shows a slight development in the direction of a stigma. Fig. I I represents a staminate flower from a carpellate plant with three stamens on a central stalk, the normal position for the gynoecium, two of the stamens having rudimentary stigmas. Fig. I 2 is an imperfectly bisporangiate flower from a staminate plant. As intimated, a great number of such variations and abnormalities of every conceivable diversity appear on both staminate and carpellate plants. They are readily intelligible on the theory that they are caused by varying and reversible sexual states. Any attempt to bring such phenomena within the limits of discrete Mendelian units, segregated and combined normally or abnormally during the reduction and fertilization stages, would appear extremely absurd to the writer. 


\section{Diversity of flower types on individual plants}

Plant no. I, a carpellate plant which had besides the normal carpellate flowers: two flowers each with 3 stigmas united below; one flower with 3 small but perfect stamens and a gynoecium with 2 stigmas; one flower with 3 sepals and a gynoecium with I stigma; one flower with 4 sepals, I stamen, and a gynoecium with 3 stigmas.

Plant no. 2, a staminate plant which had besides the numerous normal staminate flowers: one carpellate flower with a normal gynoecium with 2 stigmas but with 4 small sepals; one flower with 4 sepals and a central structure developed as a stamen on one side ending in a stigma and an ovulary on the other also ending in a stigma; one staminate flower with 4 sepals, 2 normal stamens, I rudimentary stamen, and I stamen with a stigma projecting from its side; one staminate flower with 4 sepals, I normal stamen, and I structure with 2 microsporangia and a rudimentary ovulary with 2 stigmas; one flower with 5 sepals and a central structure, part stamen with 4 microsporangia and a rudimentary ovulary with 2 stigmas; one staminate flower with 4 sepals, 4 normal stamens in a cycle, I centrally placed normal stamen, and beside this a rudimentary ovulary with a normal stigma; one staminate flower with 6 sepals, 5 normal stamens in a cycle, and a central stamen which was thick and short; one staminate flower with 5 sepals and with 5 stamens in a cycle one of which ended in a stigma; one flower with 4 sepals, 4 stamens, and I apparently normally placed central ovulary with a stigma and beside this a rudimentary ovulary also ending in a stigma; one flower with 5 sepals, 5 stamens, and a central rudimentary gynoecium with stigma.

Plant no. 3 , a carpellate plant which had besides normal carpellate flowers: one flower with 4 sepals, 2 normal stamens, and a central rudimentary ovulary with 2 stigmas; one flower with 4 sepals, 3 normal stamens, and a carpellate structure with 5 stigmas; one flower with 4 sepals and a bladdery ovulary with 4 stigmas.

Plant no. 4, a carpellate plant which had besides numerous normal carpellate flowers: one carpellate flower with a microsporangium in the side of the ovulary; one staminate flower with 
5 sepals and 4 stamens, one of the stamens with 2 microsporangia and stigma; one flower with a gynoecium with 2 stigmas, and a normal stamen connected with the base of the ovulary; one flower with 3 sepals, 2 normal stamens, and 2 stamens grown together by their filaments, the one with 4 microsporangia and a rudimentary ovulary in its side, the other with 2 microsporangia and an ovulary with a normal stigma in its side; one staminate flower with 2 sepals and 3 normal stamens; one staminate flower with 4 sepals and 2 normal stamens.

Plant no. 5, a staminate plant having besides the usual types of staminate flowers: one flower with 3 sepals, 3 stamens, and in the center I normal carpel with a stigma and I rudimentary carpel with a stigma; one flower with 6 sepals, 4 normal stamens, I rudimentary stamen, and a central gynoecium with 3 stigmas; one flower with 5 sepals, 3 normal stamens, and a central structure staminate on one side with 4 microsporangia, and carpellate on the other side with a typical stigma; one flower with 5 sepals and 5 stamens, one of the stamens with a stigma; one flower with 5 sepals, 2 normal stamens, a rudimentary structure of indefinite nature, and a gynoecium with I normal stigma and I rudimentary stigma.

Such is the usual character of the plants with reversed and confused sexuality. They can be obtained in great numbers in the winter and are very convenient for study. There is also much diversity in the time and degree of reversal of the sexual state in the long-lived carpellate individuals. Two individual records follow:

Plant no. I was a decidedly carpellate plant which produced eight seeds and was strong and vigorous. It sprouted at the lower nodes of the inflorescence and produced abundant carpellate flowers on these branches also, while the top of the main stem was dying off. This plant was at first taken to be a pure carpellate individual, but later two flowers developed on a branch, each with a fully developed stamen.

Plant no. 2 was a carpellate plant which produced seed and later developed a lateral branch with typical carpellate flowers, and at the same time continued to grow at the tip of the main axis on 
which a staminate flower was produced. One cannot tell, therefore, whether a plant will continue "pure" or whether it will reverse its sexual state until it actually begins to die.

\section{Sex intergrades and sex reversals}

Plots 2, 6, and 7 were planted out of doors under normal conditions. Not a single intermediate plant was developed, and not a sign of sexual confusion in the floral characters was found. Plots 6 and 7 were studied with great care. No record was kept of the ratio between staminate and carpellate plants of plot 2. Plot 6 had I 24 carpellate and I 22 staminate plants, all absolutely pure in sexual expression. Plot 7 had 86 carpellate and 83 staminate plants, all pure as to sexual expression. Plots 4, 5, 8, 9, IO, I I, I2, $\mathrm{I}_{3}$, and $\mathrm{I}_{4}$ were studied for sex ratios and ratios of pure plants to those of mixed sexual expression. The numbers of carpellate to staminate plants in the greenhouse experiments, of which definite records were kept, are shown in table II.

TABLE II

\begin{tabular}{|c|c|c|}
\hline Plot no. & Carpellate plants & Staminate plants \\
\hline $3 \ldots \ldots \ldots \cdots \cdots$ & 73 & 77 \\
\hline $4 \ldots \ldots \ldots \ldots \ldots$ & II 4 & 132 \\
\hline $5 \ldots \ldots \ldots \ldots \ldots$ & 53 & 39 \\
\hline $8 \ldots \ldots \ldots \ldots \ldots$ & 44 & $4 I$ \\
\hline $9 \ldots \ldots \ldots \ldots \ldots$ & 43 & 34 \\
\hline ro............... & 23 & 30 \\
\hline II $\ldots \ldots \ldots \ldots \ldots$ & I 8 & 13 \\
\hline I $2 \ldots \ldots \ldots \ldots \ldots$ & 36 & 17 \\
\hline r $3 \ldots \ldots \ldots \ldots \ldots$ & 43 & 31 \\
\hline $14 \ldots \ldots \ldots \ldots \ldots$ & 47 & 23 \\
\hline Total. & 494 & 437 \\
\hline
\end{tabular}

The percentages of plants with mixed sexual expression to those of pure sexual expression are given in table III. The plants were removed as soon as they showed a definite reversal to the opposite sexual state, or if they had not reversed they were pulled up when they began to die. In the nine plots which were studied for purity, reversal, or mixed sexual characters, therefore, the following proportions were found. Out of a total of $42 \mathrm{I}$ carpellate plants I67 were pure and 254 were of mixed sexual expression, or $39+$ 
per cent pure and $60+$ per cent mixed. Of the 360 staminate plants 144 were pure in sexual expression and 216 mixed, or 40 per cent pure and 60 per cent mixed. It will be noted that a much higher percentage of intermediates was obtained in the plantings of the winter of I9I9-1920 than in the winter of I9I8-I9I9. This is apparently due to the fact that the plants in I9I9-1920 received the minimum amount of light, since the plantings were made in November and December, instead of in January and February. Plots II and I2 show the greatest degree of reversal of sex, and these plots were planted on December I $_{9}$ in the north side room of the greenhouse which receives the minimum amount of light and was also kept at a lower temperature.

TABLE III

\begin{tabular}{|c|c|c|c|c|}
\hline \multirow{2}{*}{ Plot no. } & \multicolumn{2}{|c|}{ Carpellate PLANTS } & \multicolumn{2}{|c|}{ Staminate plants } \\
\hline & Pure & Mixed & Pure & Mixed \\
\hline $4 \ldots \ldots \ldots \ldots \ldots$ & 60 & 54 & 75 & 57 \\
\hline $5 \ldots \ldots \ldots \ldots \ldots$ & 23 & 30 & 19 & 20 \\
\hline $8 \ldots \ldots \ldots \ldots$ & 25 & I9 & 12 & 29 \\
\hline $9 \ldots \ldots \ldots \ldots \ldots$ & I9 & 24 & 5 & 29 \\
\hline 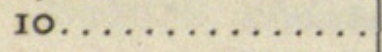 & 7 & 16 & I3 & 17 \\
\hline Ir $\ldots \ldots \ldots \ldots$ & 2 & I6 & 2 & II \\
\hline I $2 \ldots \ldots \ldots \ldots \ldots$ & 4 & 32 & 4 & 13 \\
\hline I $3 \ldots \ldots \ldots \ldots$ & I 7 & 26 & 9 & 22 \\
\hline $14 \ldots \ldots \ldots \ldots \ldots$ & 10 & 37 & 5 & I8 \\
\hline Total.... & 167 & 254 & I 44 & 216 \\
\hline
\end{tabular}

The ratios of plot II are as follows: carpellate individuals, II + per cent pure carpellate and $88+$ per cent intermediates; staminate individuals, $15+$ per cent pure staminate and $84+$ per cent intermediates. Taking the two plots together the ratio is II+ per cent pure carpellate to $88+$ per cent intermediate carpellate, and 20 per cent pure staminate to 80 per cent intermediate staminate. It is probable that if these plants had been more carefully spaced and cared for, every individual, both staminate and carpellate, would have developed both sexual states sooner or later.

It will be noted that the plants of plots 8-I4 had two generations of known sporophyte ancestors which had shown no confusion of sex. Plots $3,4,5,6$, and 7 had pure sporophyte parents, but plots 
3,4 , and 5 produced large numbers of intermediates and reversals, while plots 6 and 7 produced only pure carpellate and pure staminate plants. It is evident, therefore, that the large numbers of intermediates and reversals of plots 3,4 , and 5 were due entirely to the conditions of environment and not to a difference in genetical constitution as compared with the plants of plots 6 and 7 . The abnormal environment caused a reversal in the staminate seedling from the male to the female state, and this resulted in the expression of carpellate structures in varying degrees of extent and intensity. The same environmental conditions caused a reversal in the carpellate plants from a female to a male condition, either in the early seedling stage or at any later time until the approach of old age and death. This reversal is also of varying degrees of extent and intensity as in the staminate plant. In extreme cases the carpellate plants produced normal stamens with fully developed pollen, which is shed in the usual manner. In other cases, although stamens were developed, the pollen was imperfect and the anthers dried off without dehiscing. In the reversal of the staminate plant there were also occasional normal carpellate flowers produced with their entire morphology typically carpellate, but usually the structures were abnormal.

Enough progress has now been made in the direction of sex control in the hemp to take a quantity of seeds and produce at will either a stand consisting of individuals with pure male or female expression, pure staminate or carpellate plants, or a stand of individuals in which $50-90$ per cent are of mixed sexual expression, although the sex was apparently already definitely determined as male or female in the sporophyte embryo.

\section{Character and degree of sexual reversal}

The carpellate plants, which are somewhat intermediate from the first, or which sooner or later reverse their sexual expression, produce normal seeds, and some plants were grown from such seeds in the greenhouse. Since the greater part of the development of the individual is complete before anthesis, the carpellate plants continue to appear typically carpellate after reversal except in the floral structures. If partial reversal takes place much before 
anthesis, it would be difficult to detect, because the young plants are not so dimorphic as the mature individuals. The time of reversal after anthesis may be at any stage until extreme old age. As stated, some individuals produce only imperfect stamens with defective pollen and indehiscent anthers, while others produce normal staminate flowers with dehiscent anthers and pollen which appears normal in every respect. In such cases the sexual expression usually involves the entire flower, and the perianth is typically staminate, like the perianth on a staminate plant. The reversal from femaleness to maleness is of varying degrees, both as to the perfection of the stamens and the number of flowers produced.

The staminate plants of an intermediate sexual expression are usually so at the beginning of anthesis, few staminate individuals developing carpellate structures at a later stage unless they do so from the beginning. Some, however, continue to be more or less intermediate up to the time of old age and death. If some method of rejuvenation could be employed, it is probable that plants purely staminate at first might be induced to become carpellate later, but under ordinary conditions the change in the staminate plants, as in the carpellate plants, progresses from femaleness to maleness. The reversal in the staminate plants is usually less complete than in the carpellate plants, probably for the reason that senility usually sets in soon after the beginning of anthesis, while in the carpellate plants the long active period after anthesis has begun permits the efficient environmental factors to have full effect in the growing vegetative tissues.

A few special cases were carefully studied in relation to the progressive change in sexual expression. A number of individuals appeared normally carpellate and produced two or three normal seeds, and then gradually changed to the staminate condition, until finally, before they began to die of old age, purely male sex was being expressed. Nothing but typical staminate flowers with dehiscent anthers and normal pollen were being produced. Femaleness had been changed completely to maleness; and this change had taken place in plants which in the seedling stage had been determined as carpellate individuals with decided characters peculiar to the female state. There is but one inevitable rational 
conclusion. The decided sexual dimorphism exhibited by the sporophyte of the hemp is not due to some homozygous or heterozygous condition, and is not due to the absence of one or the other sex potentialities. The dimorphism depends on a fundamental state inherent in the cells, either male or female, which can be reversed by the operation of an abnormal environment in the vegetative tissues during the life of the individual. The sexual state is not controlled by segregating Mendelian units. The reversions and transformations are not related to the synaptic associations and segregations of chromosomes in the reduction division, nor in the homozygous or heterozygous mixtures of chromosomes during fertilization. There can be no question that it would be possible with proper environmental control of the original gametes and zygote to determine the original sexual state of the embryo as readily as the established sexual state can be shifted later, either from male to female or from female to male.

In the winter plots a few individuals approached what might be regarded as a monoecious condition. These plants were intermediate in robustness and about as tall as the staminate plants. They developed stamens and gynoecia and abnormal sporophyll structures from the beginning and continued to do so to the end. It is suggested that these individuals were either of a distinct genetic constitution like a typical monoecious plant with the vegetative tissues in a neutral state in respect to sex until the incepts of the flower buds appear, or else the sporophyte embryos were determined as staminate plants of only a slight degree of maleness, and were then reversed to a neutral condition, as in the ordinary types, by the influence of the environment at an early stage, perhaps soon after sprouting. From the neutral meristematic tissue the floral parts would then be thrown either into the male or female state. In cases where a sporophyll is partly staminate and partly carpellate, it must be assumed that the determination of the sexual state was delayed until the tissues were considerably developed, and that then maleness was established at one point and femaleness at another, probably depending on the metabolic level of the cells involved. If the intermediate nature of these plants is due to some definite genetic constitution, 
it should be possible to develop a race of hemp which would show monoeciousness under ordinary field conditions. The genetic change from a dioecious to a monoecious condition would be caused by some change in one or more hereditary factors or one or more mutative additions or losses. Such factors, of course, may be present in any number of species, but the point to be emphasized is that such factors or states have no fundamental relation to the sexual nature of the plant, but are only causes which determine more or less definitely at what stage of the ontogeny the sexual state is established. Whether there are special factors in chromosomes for monoeciousness and dioeciousness appears not to be definitely known. In any event, the monosporangiateness or bisporangiateness must not be confused with the sexual state. The one condition or the other simply determines at what stage of the life history a definite sexual state is established, depending on a certain metabolic level, a certain degree of senility of the tissues, or a certain differentiation of the cells. Whether the bisporangiate monoecious and dioecious conditions are due to definite factors or simply to a difference in general constitution, the sexual state in either case could be changed by external causes. There is no fundamental difference between an organism with bisporangiate flowers and one with monoecious flowers as regards sex. The main difference is simply an earlier or later stage of vegetative growth at which the one or the other sexual state is established in a given cell, tissue, or organ. Since it is plain that this is the case, it is not reasonable to suppose that any new principle is involved in passing from a monoecious to a dioecious species, since we know that there is every gradation between bisporangiateness and dioeciousness. The experiments on hemp show that even in a dioecious species with marked dimorphism the male state or the female state is possible in any tissue of a sexual organism, the readiness or difficulty of inducing a change from the one condition to the other depending on various internal and external causes.

Several seeds were obtained from decidedly intermediate plants, but none of them sprouted. This does not necessarily imply any constitutional defect, since many of the seeds from the 
dwarfed ordinary carpellate plants are also defective and do not sprout so readily as those grown under normal conditions.

Seeds collected from carpellate plants which later developed stamens were planted in plot 15 . There was apparently no difference in the behavior of the plants from these seeds from those raised from seeds obtained from pure parents out of doors, but the number of plants was too small to draw any definite conclusions. One would expect that the embryos of seeds developed under abnormal conditions would show less fixity of the sexual state than those developed under normal conditions. Since practically all the seeds from the out of doors "pure" parents will show reversal of sex with proper abnormal conditions, however, probably the only way to get any definite data indicating a difference would be to test such seeds out of doors in comparison with ordinary seeds. In such an experiment, however, the plants should be grown in an environment which will just keep the plants from normal seeds pure. Such limits can probably be discovered.

\section{Recent work}

Various investigators have made observations on the sex ratio of hemp. It is not necessary to refer to the older papers here except to state that a considerable diversity in the proportion of the staminate and carpellate plants has been found. Roughly speaking, the ratio of carpellate to staminate plants is $\mathrm{I}: \mathrm{I}$, with a deviation in either direction of at least 50 per cent in extreme cases, even when large numbers are counted.

In IgI6 PRICHARD (2) published his results on changing the sex in hemp by mutilation. By removal of leaves and flowers, and by certain other treatments, he was able to obtain 17.8 per cent of reversals in the established sexual state. In all, 25 carpellate and 4 staminate plants showed reversal of sex.

YAMPOLSKY (7), working with Mercurialis annua L., found that some carpellate plants produced staminate flowers and some staminate plants produced carpellate flowers, and that both staminate and carpellate plants showed gradations in degree of maleness and femaleness. He also found that the offspring of 
selfed carpellate plants are carpellate or prevailingly carpellate, and the offspring of staminate plants are staminate or prevailingly staminate. This condition is probably what should be expected if the seedlings are grown in the same environment as the parents. It would be interesting to know whether this condition could be modified by raising the seedlings in a fundamentally different environment. The writer knows from experience, however, that Mercurialis is a much less satisfactory plant for study than hemp, because of its minute flowers, less prominent dimorphism, difficulty of gathering seed, etc. YAMPoLsky (8) also found flowers with confused sexual expression much like what is reported in this paper for hemp. He rightly concludes that "a factorial hypothesis of sex cannot explain these results," that is, the periodic alternation of sex in the course of the plant's development.

I have already shown (3) the significance of the change in the sexual state of a bisporangiate flower, taking as examples the cones of a Selaginella and the flowers of a Bromus, and showing that the establishment of the sexual state in the organs involved had nothing to do with a Mendelian segregation depending on the synapsis and segregation of chromosomes.

Stout (6) has made a study of intersexuality in Plantago lanceolata, and found that there is a wide range of variation in the degree in which maleness is expressed. He also found that femaleness varies in the degree of its expression.

Davey and Grbson (I) found that the changes in the sexual state, which they studied in Myrica Gale, were in some way associated with environmental conditions. The relative proportion of carpellate plants was found to be greater in the wet than in the dry areas. Myrica Cale would probably be a desirable perennial species for experiments on the environmental control of the sexual state, as the hemp is for a short-lived annual.

The writer (4), while studying the intermediate plants of Morus alba, found a staminate tree that had one large reversed lateral branch and a second small one at the top. These branches were bearing fruit, but although they were decidedly carpellate, they were so only to a degree, for both were still producing staminate catkins. The seeds of this fruit were perfectly normal, and the 
- writer now has a progeny of young trees from this "male individual." This reversal of the sexual state took place in the meristematic tissue of the staminate sporophyte. A state which in general always causes the expression of male characters through some internal cause was changed to a new sexual state or a neutral condition by which the sexual expression in the incipient aments was easily thrown into the female or the male state, while the rest of the tree, consisting of numerous large branches, was in such a sexual state that maleness was invariably expressed in the incipient aments. This tree functions the same from year to year. All such cases, as well as the remarkable behavior of hemp, show that a Mendelian hypothesis of sex is at present not only untenable, but is absurd in the extreme. It is not even necessary to have such a hypothesis as an explanation of sex in the higher animals in which the nuclei of the two sexes show an allosome difference.

I have stated (3) that the great abundance of intermediates among the winter hemp plants was probably due to the abnormal environment, mainly a lack of light. The statement was also made that hemp was "a dioecious plant which shows sexual dimorphism even in its remote vegetative parts, but numerous individuals which are thus specialized have the ability to produce the opposite primary sexual generation and sexual cells, without any manipulation whatever being employed, except that they were grown in an unusual environment." It behooves the advocates of the hypothesis of homozygous and heterozygous constitutions to show how their hypothesis works in these numerous examples now on record before attempting to confuse biological literature with an apparently untenable theory. The present work on hemp shows that the attempt to analyze the sexual constitution of monosporangiate or bisporangiate plants from ratios which appear in cultures is of little value unless it has previously been shown that the plant reacts the same to all environments. In any dioecious species which has sex intergrades, and there are apparently few which do not have them, it is of no genetic importance to discover that a certain "pedigreed" individual has produced so many "males," "females," and "hermaphrodites," unless it is definitely known that the same kind of seeds would not give a different progeny if 
grown in an entirely different environment. Sex goes beyond the organized visible structure of the protoplasm, and is probably bound up with the atomic or molecular structure, or dependent on some physical state which is reversible in most cells. It seems impossible to explain the known facts of sexuality and sexual morphology by any activities or movements of the larger structural units of the protoplast, such as chromosomes, chromatin granules, centrosomes, nucleoli, chondriosomes, etc.

The geneticist must give as much attention to the expression of heredity as to the analysis of hereditary factors, and it is becoming more and more apparent that the environment plays a very prominent part in such expression, the characteristics of the individual being decidedly different when developed under one environment from what they would be if developed under another. So far as sexuality is concerned, the cells may be in such a state of equilibrium that closely associated groups may be thrown into the opposite sexual state and be differentiated as such simply because the one area is at a different metabolic level from the other. It is a common occurrence, therefore, not only in hemp but in great numbers of species, for sporophylls to be microsporangiate in one part and megasporangiate in another, or to have the characters peculiar to maleness in one part and those peculiar to femaleness in the other.

Hemp is recommended as perhaps the most convenient plant to grow for experimental purposes, for classes in genetics, and to illustrate confusion of sexual expression and sex reversal. The flowers appear in from 30 to 36 days if planted about December 10, and the staminate plants can mostly be studied before it is necessary to pay attention to the carpellate individuals. The extreme dimorphism, the lack of vestigial parts in the normal flowers of the opposite set of sporophylls, the response in size of the plant at various seasons, and other peculiarities combine to make hemp of unusual interest to the student.

The writer is under obligations to Mrs. BAyARD TAYLOR for much assistance in the work on plots $8,9, \mathrm{I}_{3}$, and $\mathrm{I}_{4}$; and to Mr. R. J. SIM for assistance in the illustrations. 


\section{Summary}

I. Hemp planted in spring in the open, under normal conditions, developed as pure carpellate and pure staminate individuals. There is no confusion of sexuality.

2. The ratio between carpellate and staminate individuals is about $\mathrm{I}: \mathrm{I}$, with a large deviation in either direction for various plots.

3. Hemp planted in winter in the greenhouse on shallow benches with low light intensity showed great confusion in sexual expression. Abundant irregularities were produced, such as stamens with normal stigmas and structures partly carpellate and partly staminate, as well as more typically bisporangiate flowers and flowers typical of the opposite sexual state.

4. Both carpellate and staminate plants showed reversal in their growing period to the opposite sexual state.

5. In extreme cases $88+$ per cent of carpellate plants showed reversal to maleness, and 80 per cent of staminate plants showed reversal to femaleness.

6. Both staminate and carpellate plants, although they showed decided sexual dimorphism, contained all the factors and abilities of both sexes. There is no question of a homozygous or heterozygous condition involved. The staminate and carpellate individuals contain the potentialities for the perfect development of the opposite sex. Reversal of the sexual state takes place in the vegetative tissues, and has no relation to a reduction or segregation of chromosomes or their possible hereditary factors.

7. The sexual reversal is of all degrees of intensity, from very imperfect expressions of the opposite organs to completely normal development.

8. Sexuality is a state or condition not Mendelian in nature, but related to the functional activity of the plant and profoundly influenced by environment. Maleness and femaleness in hemp are probably controlled by the metabolic level of the cells, and sex reversal takes place when the metabolic level is decidedly changed or disturbed.

9. Any tissue in its growth may be in a neutral state of varying degrees of intensity, and during its continued growth can pass 
from one state to the other without any reference to chromosome segregation or combination which are the ordinary causes of Mendelian phenomena.

Io. Sex is subject to experimental control in the individual in such dimorphic, dioecious species as hemp, and such control can be exercised in various ways by changing the ordinary factors of environment, and, therefore, presumably also by chemical and physical stimuli of various kinds.

Ohio State University

Columbus, OHio

\section{LITERATURE CITED}

I. Davey, A. J., and Gibson, C. M., Note on the distribution of sexes in Myrica Gale. New Phytol. 16:147-151. I917.

2. Prichard, F. J., Change of sex in hemp. Jour. Heredity 7:325-329. I9I6.

3. Schaffner, John H., The expression of sexual dimorphism in heterosporous sporophytes. Ohio Jour. Sci. 18:10I-I25. I918.

4. - The nature of the dioecious condition in Morus alba and Salix amygdaloides. Ohio Jour. Sci. 19:409-416. 1919.

5. - Complete reversal of sex in hemp. Science N.S. 50:3II-3I2. I9I9.

6. Stout, A. B., Intersexes in Plantago lanceolata. Bot. Gaz. 68: ro9-133. I9I9.

7. YAMPolsky, Cecil, Inheritance of sex in Mercurialis annua. Amer. Jour. Bot. 6:410-442. I9I9.

8. - Sex intergradation in the flowers of Mercurialis annua. Amer. Jour. Bot. 7:95-100. 1920.

\section{EXPLANATION OF PLATE XI}

All the figures are slightly magnified.

Fig. I.-Normal staminate flower from staminate plant just before dehiscence of anthers.

Fig. 2.-Normal carpellate flower from carpellate plant; perianth is sheath with oblique limb; sheath or calyx cut open to expose ovulary.

Fig. 3.-Nearly perfect carpellate flower from base of staminate inflorescence on staminate plant; 4 sepals fused together; side of calyx torn open to expose ovulary; in staminate plants usually most perfect carpellate flowers develop first.

FIG. 4.-Stamen with stigma; from staminate plant.

FIG. 5.-Ovulary from carpellate plant with stamen growing from one side; ovulary is flat on side from which anther projects. 

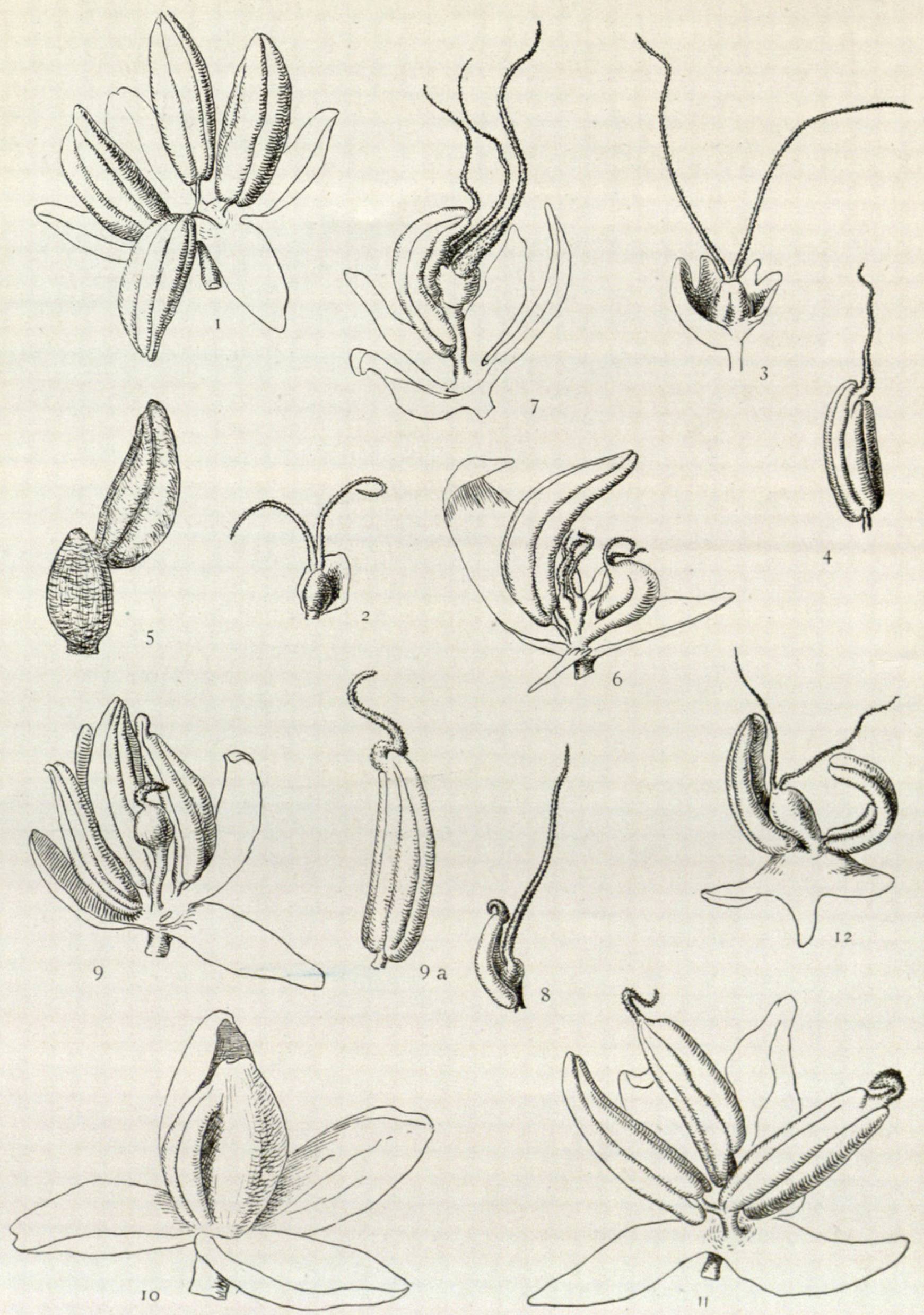

SCHAFFNER on HEMP 


\section{$2 \mathrm{BHL}$ Biodiversity Heritage Library}

Schaffner, John H. 1921. "Influence of Environment on Sexual Expression in Hemp." Botanical gazette 71(3), 197-219. https://doi.org/10.1086/332818.

View This Item Online: https://www.biodiversitylibrary.org/item/109572

DOI: https://doi.org/10.1086/332818

Permalink: https://www.biodiversitylibrary.org/partpdf/224256

\section{Holding Institution}

Missouri Botanical Garden, Peter H. Raven Library

\section{Sponsored by}

Missouri Botanical Garden

\section{Copyright \& Reuse}

Copyright Status: Public domain. The BHL considers that this work is no longer under copyright protection.

This document was created from content at the Biodiversity Heritage Library, the world's largest open access digital library for biodiversity literature and archives. Visit BHL at https://www.biodiversitylibrary.org. 